\title{
ENEPGY CONSEYVYTION:
}

POLICY HSUES AND

END-USE SCENARIOS OF

\section{SA MIRGS ROTRTMAL}

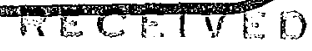

I. AWREMCE

DERLER LABORMTOW

DEC 121978

LBRARY AND

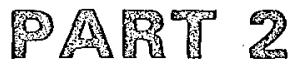

TRADEOFRS OR RUMTIMIPL SOLID MASTE

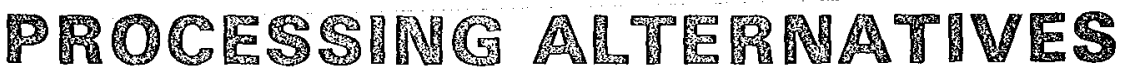

\section{TWO-WEEK LOAN COPY}

This is a Library Círculating Copy which may be borrowed for two weeks.

For a personal retention copy, call

Tech. Info. Division, Ext. 6782

September 1978

Lawrence Berkeley Laboratory

University of California, Berkeley 


\section{LEGAL NOTICE}

This report was prepared as an account of work sponsored by the United States Government. Neither the United States nor the Department of Energy, nor any of their employees, nor any of their contractors, subcontractors, or their employees, makes any warranty, express or implied, or assumes any legal liability or responsibility for the accuracy, completeness or usefulness of any information, apparatus, product or process disclosed, or represents that its use would not infringe privately owned rights.

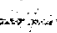

Printed in the United States of America

Available from

National Technical Information Service

U. S. Departmient of Commerce

5285 Port Royal Road

Springfield, VA 22161

Price: Printed Copy, $\$ 5.25$ Domestic; $\$ 10.50$ Foreign

Microfiche, \$3.00 Domestic; \$4.50 Foreign 


\title{
ENERGY CONSERVATION: POLICY ISSUES \\ AND END-USE SCENARIOS OF
}

SAVINGS POTENTIAL

\author{
LBL PROJECT STAFF \\ Peter Benenson \\ Ricardo Codina \\ Bonnie Cornwall \\ David Dornfeld \\ Barbara Greene \\ Jon Elliott \\ Willett Kempton \\ Catherine Langlois \\ Harold Nelson \\ John Nides \\ Forest Rouse \\ Carola Sullam \\ CONSULTANTS \\ Richard Barnes \\ Dow Chemical, USA \\ Norman M. Bradburn \\ Department of Behavioral Sciences \\ University of Chicago \\ Lawrence Berkeley Laboratory \\ University of California, Berkeley \\ September 1978
}

Prepared for the U.S. Department of Energy under Contract W-7405-ENG-48 submitted to Dr. Clark Bullard Director, Office of Conservation and Advanced Energy Systems Policy

U.S. Department of Energy

PRINTED ON RECYCLED PAPER 
TABLE OF CONTENTS

PART

1. SUMMARY

2. TRADEOFES OF MUNICIPAL SOLID WASTE PROCESSING ALTERNATIVES

1) Economics of Garbage Collection

2) Mechanical vs. Home Separation of Recyclables

3. POLICY BARRIERS AND INVESTMENT DECISIONS IN INDUSTRY

1) A Methodology for the Identification of Potential Barriers to Industrial Energy Conservation

2) The Process of Industrial Investment Decisionmaking

4. ENERGY EFFICIENT RECREATIONAL TRAVEL

1) An. Information System to Promote Energy Efficient Recreational Travel

2) Recreational Travel: National Importance and Individual Decision-making

5. ENERGY EFFICIENT BUILDINGS.

1) The Causes of Litigation Against Energy Conservation Building Codes

2) A Description of the Building Process

6. END-USE ENERGY CONSERVATION DATA BASE AND SCENARIOS

1) Residential

2) Commercial

3) Transportation

4). Industrial 


\section{FOREWORD}

The enclosed work is based upon our previous research during this fiscal year, contained in "Construction of Energy Conservation Scenarios: Interim Report of Work in Progress", LBL 7834, June 1978. The focus of our current work was determined in consultation with the Director and staff of the Conservation and Advanced Energy Systems Policy office, DOE, following their review of our interim report. At that point we agreed on several guidelines for our subsequent work:

1. Take a wholistic view of energy conservation policies by describing the overall system in which they are implemented;

2. Provide analytical tools and sufficiently disaggregated data bases that can be adapted to anwer a variety of questions by the users;

3. Identify and discuss some of the important issues behind successful energy conservation policy;

4. Develop an energy conservation policy in depth.

In addition to these guidelines, we selected five subjects to investigate.

1. Recycling: an analysis of the energy, economic, and environmental tradeoffs between landfill and combined programs of resource recovery and energy generation from waste.

2. Industrial Decision-Making: a methodology to identify potential barriers to energy conservation by analyzing how a conservation measure's attributes interact with the characteristics of an industrial subsector.

3. Recreational Travel: information strategies to effect a modal shift to public transit for the recreational trip.

4. Residential and Commercial Buildings: an examination of court cases against new energy efficient building codes and suggestions for avoiding future litigation.

5. End Use Energy Conservation Data Base: completion of energy conservation scenarios by calculating the energy conservation potential of specific measures applicable to particular end uses.

Our current work results from the application of the overall guidelines to the above subjects. For example, we have described the system in which each policy or issue is set by the use of flowcharts and accompanying text. In some cases, the flowchart describes a physical activity (constructing buildings or recycling waste materials). In other cases, it describes a decision-making process (industrial investment or transportation modal choice). 
We have provided disaggregated quantitative data wherever they are relevant-recycling, recreational travel, industrial decision-making, and the end use scenarios. We have discussed several policy issues for which these data are relevant:

1. What are the tradeoffs between landfill and combined resource recovery-garbage to energy programs. 2. What are the stated and underlying causes of law suits against building codes. 3. How can the present modal distribution that is heavily welghted toward the automobile be shifted to public transit for the recreational trip.

4. What are the conditions that present barriers to energy conservation investment in the industrial sector.

In the case of recreational travel, we have developed a specific policy to link national parks with public transit.

Our results for each of the five subjects are bound separately; the subjects do not readily lend themselves to integration and the DOE staff did not think it would be useful to attempt one. We have issued a separate summary volume for those who want an overview of all the subjects investigated. 


\section{ACKNOWLEDGMENTS}

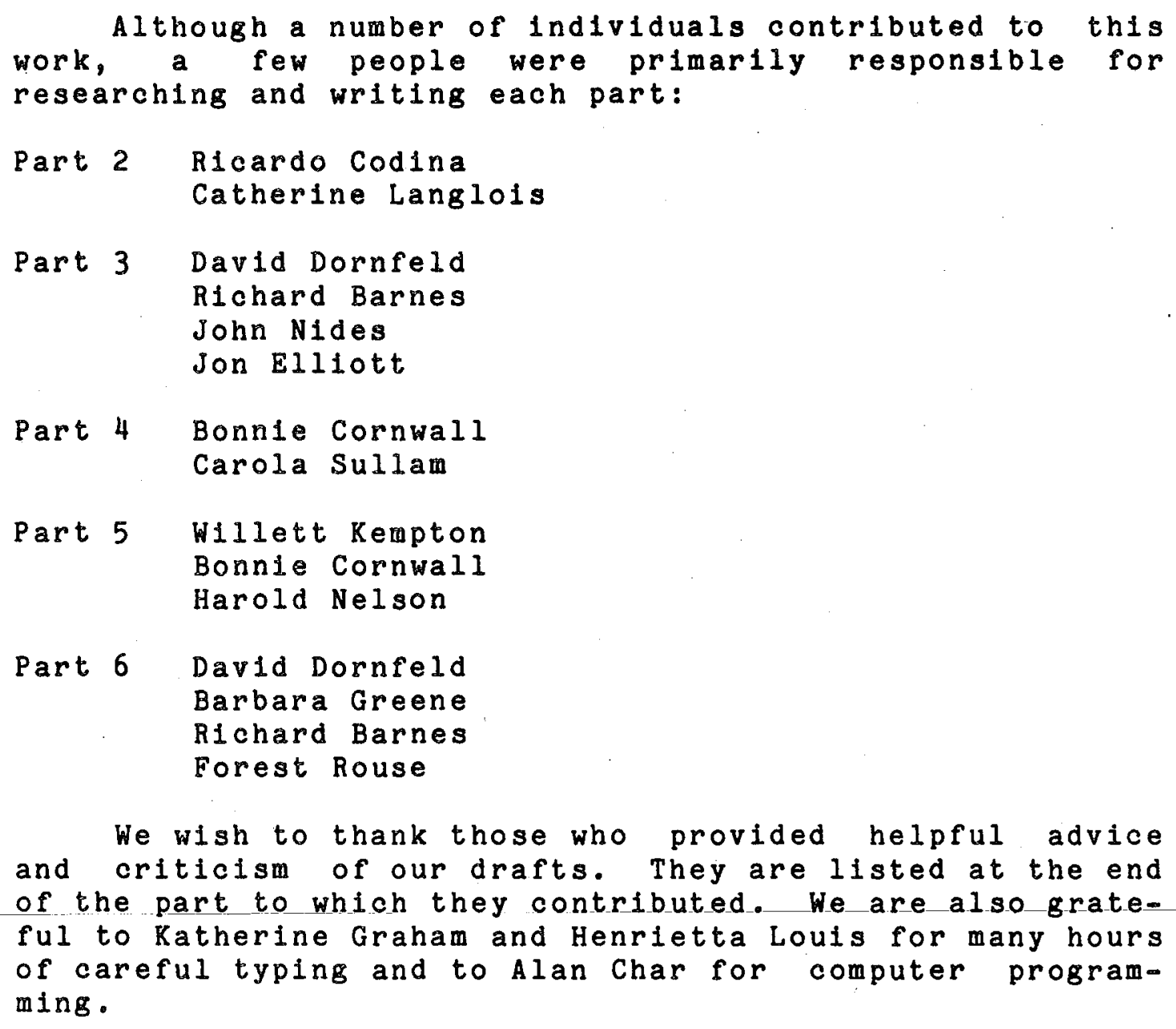


Table of Contents

List of Tables

page

I. Summary

A. Objectives and Issues

B. Conclusions

II. The Economics of Garbage Processing Techniques

A. Capital Intensity and Operating Costs

B. Energy Balances

C. Energy Quality and Pollution Problems

D. Marketing Problems

III. Mechanical Versus Home Separation of Recyclables

A. Introduction

B. Potentially Recoverable Materials

17

C. Potentially Recoverable Energy

22

D. Cost Considerations

1. Cost of Source Collection

26

2. Costs of Mechanical Recovery

IV. Bibliography

V. Appendix: The Resource Recovery Process 


\section{LIST OF TABLES}

Table la. Capital Cost Comparison Alternative MSW Recovery Systems

Table 1b. Operating Cost Comparison Alternative MSW Recovery Systems

page

8

Table 2. Relative Owning and Operating Costs of Resource Recovery Systems -- Berkeley, California 10

Table 3. Cost/Ton of Waste Landfilled and Landfill

Closure Dates For The Los Angeles Area

Table 4. Energy Efficiency of Alternative

Fuel processes

Table 5. Chemical Analysis of RDSF and Bituminous Coal ( $\left.p_{i}^{\prime}\right)$

Table 6. Stack Emissions and Waste Water Flows 13

Table 7. Emissions Per Million BTU Gross Heat 14

Table 8. Comparison Between Refuse Derived

Gas and Natural Gas

Table 9. Price of MSW Derived Energy

Table 10. Recyclables in the Waste Stream 17

Table 11. Mechanical Separation Recovery Levels 18

Table 12. Source Collection Efficiencies 19

Table 13. Comparative Material Recovery Efficiencies

Table 14. Potential Energy Savings -Source Separation

Table 15. Comparative Energy Savings For Newsprint Recovery 23

T'able 16. Potential Heat_Value of News-pint and MSW Fuel

Table 1. Comparative Energy Savings For

Multi-Materials Recovery
able 18. Energy Use for Mechanical Processing and Recovery of MSW

Table 19. Energy Consumption In Materials Collection

Table 20. Total MSW Collection Cost Impact of Separate Paper Pick-Up

Table 21. Total MSW Collection Cost Impact Rack Method of Paper Pick-Up

Table 22a. Source Separation Collection Costs Marblehead and Somerville, Massachusetts able 22b. Source Separation Collection Costs California Examples

Table 23. Disposal Costs (Dollars Per Ton)

Table 24. Projected Revenue -- Source Separation 30

Table 25. Revenue From Recycling Alternatives 30

Table 26. Capital Costs for Materials Recovery 31

Table 27. Cost Fstimates Adjusted for Ferrous Metal Recovery For A. M. Kinney Process 


\section{SUMMARY}

\section{A. OBJECTIVE AND ISSUES}

The objective of this part is to assess the comparative performance and advantages of the various garbage processing or disposal (landfill) techniques, and to address the issue of large-scale recycling of waste material.

Five general methods are discussed: close-in landfill, remote landfill, refuse derived solid fuel (RDSF), pyrolysis and incineration. Landfilling is one of the most prevalent garbage disposal techniques in use. The method is inexpensive, requires small capital outlays, and is relatively energy efficient. But landfills are a waste of valuable land. Close-in garbage disposal sites are slowly reaching limits and have to be abandoned for sites more remote from the municipalities served. Moreover, garbage generation is seen to increase in future years, reaching 5 pounds per person per day in 1990 against 3.4 pounds per person per day in 1975 (U.S. Environmental Protection Agency 1977: 20). Since operating costs for landfills increase dramatically with distance from the area served, the economic advantage of landfill will diminish in the years to come.

Landfills can also be an environmental hazard (e.g. water contamination, production of explosive methane gas). Moreover, landfilling amounts to disposing of potentially energy-rich materials and recyclable resources. For all these reasons, increasing attention has been given to the various methods of garbage processing for energy and to the possibilities offered by the recycling of source-separated materials.

The importance of such issues is exemplified by the policies implemented in a number of states. For example, California has implemented over 130 recycling programs in different communities, while six major cities which together comprise the bulk of the state's population are considering the creation of large-scale resource recovery facilities.

The major issue at this time concerning municipal solid waste disposal is whether to continue with landill as the primary method or to use some combination of source separation, resource recovery and energy generation. The constraints surrounding this issue are capital and labor costs, technical feasibility, environmental impacts -- especially air pollution - marketability of the derived energy and recycled resources, and public cooperation.

Close-in landfill is inexpensive, but the sites are 
nearing capacity and additional close-in sites are either unavailable or extremely expensive. Remote landfill is costly -- consequently, as close landfills reach capacity, the competitiveness of MSW recovery plants must be considered. Landfill also has many negative environmental impacts, such as odor, contaminated runoff, occupation of land, etc.

\section{B. CONCLUSIONS}

No definite conclusion can be reached as to the comparative economic advantages of RDSF production, pyrolysis and incineration - only site specific analysis can determine the choice of a product because of three main sitespecific variables: design options, financing arrangements and market conditions.

Recycling of glass, aluminum and ferrous metals is compatible with energy generation whether done mechanically at the recovery plant or by the public prior to. MSW delivery. This holds because these materials must be removed prior to energy production. Of these recyclables, ferrous metals are most efficiently recovered through mechanical means. At present, glass and aluminum appears to be best recovered through public recycling and source separation programs, although this situation is subject to state-of-the-art developments in recovery equipment, local market conditions and the costs of local-collection. Newsprint represents a potential conflict because it can be either recycled or converted to energy, but the former appears more energy efficient.

An effective source separation program, in a high participation scenario, can reduce the MSW by $15 \%$. It is important to consider this potential in planning resource recovery options since any reduction in the MSW stream will have a bearing on the size of the facility that will be necessary. The conclusions in more detail are presented below.

The location of waste processing facilities is the most important factor to be taken into account when assesing the pros and cons of any particular process. MSW processing plants are of obvious interest in densely populated areas where pollution problems and in particular air pollution are most dramatic. Thus, preference for one process rather than another does not necessarily reflect economic data alone. California, for example, has imposed stringent regulations on air pollution - hence preference in this state is given to pyrolysis despite economic disadvantages (both capital and operating costs), since air pollution is negligible when it is used. Also under consideration in 
California are low-cost, package incinerators but these, too, are contingent upon federal and state evaluation of their air quality impact.

The separate collection of recyclable materals is generally compatible with garbage reprocessing centers. The degree of compatibility, however, is dependent on several factors, including the types of materials collected by each system, the market value of the recycled products, the cost of collection and the efficiency of the mechanical recovery equipment.

Newsprint recycling is the activity most potentially in conflict with operation of a resource recovery plant since removal of newsprint from the waste stream will affect the heat value of the fuel and the subsequent revenue derived. This decrease, though, is slight-around $10 \%$ - and is compensated by the higher energy savings achieved by recycling the fiber, rather than burning it. These savings are around $12 \%$ per collected ton of newsprint compared to the use of RDSF converted to steam, and almost $300 \%$ compared to RDSF converted to electricity.

Of all the materials, newsprint is the most suitable for separate collection. It has a relatively long history of profitable and successful collection both in separate vehicles and in conventional garbage trucks which have been modified. Less cost effective have been source separation programs which collect, besides newsprint, glass and metals. In some communities, high labor and other collection-related costs may seriously deter the creation of such multimaterial programs.

In other cases, however, multi-material collection can offer a favored alternative to the use of costly materials recovery equipment in a garbage processing plant. The exception to this generalization. is ferrous metals recovery where magnetic separation has a far superior recovery efficiency than separate collection. It averages $94 \%$ recovery of this metal. Source separation programs, by comparison, can reclaim $15 \%$ in a high participation scenario. However, steel cans collected separately have a much higher degree of purity than mechanically separated ferrous metal and can therefore command a higher market price, which may be an offsetting consideration in some areas. In any event mechanical recovery of ferrous metal will be cost effective even with prior removal of some of the metal by a source separation program.

The inclusion of aluminum recovery equipment at a resource recovery facility appears to be uneconomical at this time. The equipment has not been throughly demonstrated. It is costly - \$500,000 or more for a 1000 tpd 
plant -- which requires that a large volume of aluminum be recovered. At present, its not certain that sufficient aluminum is available. Regardless of whether aluminum is recycled via on-site pick-up or through recycling centers, between $25-40 \%$ of the valuable metal is likely to be collected by the public. The remaining tonnage is further reduced by inefficiencies in the mechanical recovery process. Uncertainty also results from the possibility that a beverage deposit law could significantly reduce the volume of aluminum in the waste stream.

Mechanical separation equipment can recover about $50 \%$ of the glass available. This is about the same level of recovery that can be expected from source collection, in a high participation scenario. of the two systems, source collection provides many advantages. It relies on proven technology as opposed to the equipment in mechanical systems and it recovers a higher grade of glass which can be colorsorted and readily marketed. Because of its low market value, glass is not a revenue-maker for either recovery system and so low annual costs are an important consideration. In this respect, glass recovery via source separation has the advantage of "piggy-backing" onto the collection of other more valuable materials at little extra expense.

\section{THE ECONOMICS OF GARBAGE PROCESSING TECHNIQUES}

\section{A. CAPITAL INTENSITY AND OPERATING COSTS}

Municipal waste including both residential and commercial waste can either be burned (incineration), shredded and air-classified (fuel recovery), or distilled in an oxygen deficient atmosphere (pyrolysis).

Air classification is the method used to separate the heavy fraction of the shredded waste (e.g. metals) from the light fraction (e.g., paper, organic substances). The air classifier is a multi-story blower unit that allows the heavy pieces to fall to the bottom through zig-zag chambers. The light combustible pieces are drawn through the top through a cyclone column. Both pyrolysis and incineration convert municipal waste into fuel of a different form. For example, the burning of garbage generates steam and pyrolysis leads to either gas or liquid fuel production. On the other hand, through shredding and air classification, mixed waste is prepared for use as a fuel in an unconverted form.

Any attempt to evaluate the economic pros and cons of each technique leads to difficulties since non-site specific cost comparisons pertaining to a process are impossible. Costs are necessarily site specific, and the technologies 
available are at varying degrees of development.

-The three main garbage processing technologies have been modified and tested to a varying extent according to the proceess. For example, waterwall combustion has undergone wide experimentation where as pyrolysis is still at a demonstration stage. RDSF generation ranks between the two other processes as far as testing is concerned. As a consequence, capital and operating costs are subject to varying degrees of uncertainty.

-Cost estimates for any given process are site specific since the design features, the type of financing available and the market conditions all depend on the site.

-The design features of the plant include the utilization rate of the plant (number of shifts per day), the number of process lines (on which depends the reliability of the plant), the system size, the kind and quality of the waste input, the cleaning of the garbage, the safety features, and architectural considerations.

-The type of financing available for construction of any given processing plant will also affect its cost. Among these factors are the type of loan (subsidized loan, private loan, etc.), the interest rate, the amortization period, the importance of the legal fees.

-The market conditions will clearly affect costs since the economic advantages of any resource recovery plant will depend on the fuel produced and the price of the substitute and competing fuels in the area. The location of the plant will determine the distance from potential users of the energy and materials recovered as well as from the producers of municipal waste. Both these market conditions affect cost.

Despite these reservations, a number of studies have attempted to compare the three main waste processing techniques on purely financial and economic grounds. Table 1 gives a selection of estimates of capital and operating costs for the three processes. Analysis of this table highlights the difficulties encountered by relying on cost comparisons to choose between alternative MSW recovery systems. 
Table la Capital Cost Comparison Alternative MSW Recovery Systems (1)*

Process :

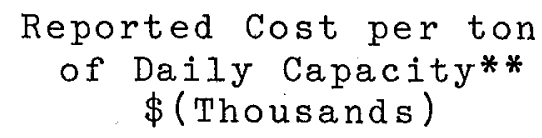

b $\quad c \quad$ e $\quad f \quad g \quad$ Mean

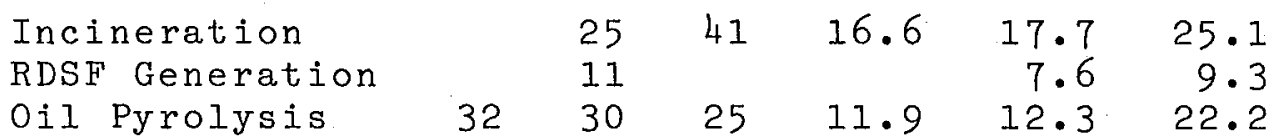

Table $1 \mathrm{~b}$ Operating Costs Comparisons Alternative MSW Recovery Systems(I)

Process:

Reported** Costs $\$ /$ ton(2)

\begin{tabular}{|c|c|c|c|c|c|c|}
\hline Incineration & 7 & & 5 & & 26 & 6 \\
\hline RDSF Generation & 3 & & 3 & 7 & & \\
\hline Oil Pyrolysis & 6 & 15 & & & 17 & \\
\hline
\end{tabular}

1). Based on a 1000 TPD Plant for most figures. References not using a 1000 TPD plant base assumed a linear relationship between cost and plant size. Numbers rounded.

2). The figures include annual administrative costs. Figures shown are net operating costs except in reference (e) where total costs are shown. They are not included in mean value calculations for annual cost.

* Source:Ritschard, et al, 1978.

* Letters refer to references listed below:

a) Midwest Research Institute 1973;

b) Lipshutz, 1978. Garbage to Energy, the False Panacea. Santa Rosa, California: Santa Rosa Recycling Center;

c) Golueke and McGauhey, 1976. "Waste Materials" in Annual Review of Energy, Volume 1. Washington, D.C.: ERDA;

d) Slattings, 1974. "The Economics of Resource Recovery," in Energy and Environment, Proceedings of the Second National Conference. N.Y: American Institute of Chemical Engineers.

e) McFarland, et al., 1972. "Comprehensive Studies of Solid Waste Disposal," Chapter6 of Net Energy Analysis of Fine Energy Systems. Oak Ridge, Tennessee: Oak Ridge National Laboroatry.

f) Franklin, Bendersky and Park, 1974. "Energy Recovery Systems for Municipal Solid Waste - A 
Technical/Economic Review and Forecast, in Energy and the Environment, Proceedings of the Second National Conference. N.Y.: American Institute of Chemical Engineers.

g) Schnelle and Yamamoto, 1975. "Potential Alternative Fuels Derivatives from Municipal Solid Waste. In Energy from Solid Waste Utilization --Proceedings of the Sixth Annual Northeastern Regional Antipollution Conference (ed. Barnett, et al); Technomix Publishing Company.

A number of authors concur about the high capital intensity of large-scale incineration compared to the other methods (McFarland, et al, 1972; Franklin, et al, 1974; Schuelle and Yamamoto, 1975). Yet, it is pyrolysis that stands out as the most capital intensive process according to Golueke and McGauhey, 1976. A Midwest Research Institute study, completed in 1973, arrives at the same conclusion as the latter (Franklin, W.E., et al, 1973).

Where operating costs are concerned varying estimates show a higher degree of consistency since all the sources investigated indicate the relatively low cost of RDSF generation and the comparatively high cost of large-scale incineration.

But such cost estimates cannot be used to estimate the advantage of any recovery system. The figures have been calculated at varying dates, do not necessarily cover the same cost components, and have not been escalated to account for inflation. Reevaluation to account for inflation would require knowledge of the cost components included and the escalation coefficient suited to each. Moreover, as data pertain to a process rather than a specific plant, the cost components which are site specific will not necessarily have been included. Consequently, the estimates shown in Table la and $1 b$ are far too low given the emerging experience of presently operating recovery facilities. For example, where Table 1 a capital costs range from $\$ 9$ to $\$ 25$ million for 1000 tons per day facilities, more recent, unpublished estimates by the Environmental Protection Agency now place capital costs at around $\$ 30$ million for a 1000 ton per day RDSF facility and as much as \$70-\$80 million for a similarly sized pyrolysis facility (Holloway 1978).

Unlike Tables $1 \mathrm{a}$ and $1 \mathrm{~b}$, Table 2 presents a cost comparison for a range of resource recovery options which are based on the constraints of a particular site, Berkeley, California. Costs are based on comparable components needed to process 64,400 tons per year. In this case, financing costs at $6 \%$ over the 20 year projected lifespan of the facilities are added to estimates of capital costs. The resulting cost of owning the facility, shown in column 1 , are approximately six times the capital costs reported in Table Ib. Similarly, the annual operating costs shown in 
column 2 of Table 2 are $3-4$ times higher than those reported in Table 1b. These higher figures are partially attributable to the less favorable economy of scale for the smaller Berkeley site, but it is also reflective of site specific considerations not included in the generalized estimates in Table $1 \mathrm{~b}$.

In the Berkeley analysis, RDSF production still compares low, but even lower in cost are package incinerators. These are small ( 25 - 50 ton per day) units which produce steam and which have not been included for evaluation in previous studies.

Table 2. Relative Owning and Operating Costs of Resource Recovery Systems - Berkeley, California

Process

Andco Torrax BSP Pyrolyser

Waterwall Combustion:

Unprocessed

Shredded

RDSF

Package Incinerator

RDSF Production

$\begin{array}{ll}\text { Cost of Owning } & \text { Annual Cost } \\ \text { Per Ton of } & \text { Of Operation } \\ \text { Daily Capacity* } & (\$ / \text { ton })\end{array}$

( $\$$ Thousands)

$\begin{array}{rr}148 & 23 \\ 98 & 26 \\ 135 & \\ 148 & 21 \\ 134 & 32 \\ 56 & 32 \\ 56 & 15 \\ & 16\end{array}$

*At $6 \%$ interest and 20 years projected lifespan. note: Based on 64,400 tons per year. Relative costs were obtained from manufacturers' estimates, escalated where appropriate at 10 percent to 1978 prices. $20 \%$ contingency was added to manufacturers' estimates on the energy recovery systems plus $\$ 200,000$ for a one-mile eight-inch steam pipe line. Includes labor, maintenance, utilities, residual disposal.

Source: Garretson, et al 1978b: 63 .

The above restrictions on the validity of data are also applicable to landfill statistics although this garbage disposal method is by far the most extensively used. However, the increase in the cost of landfilling with the distance of the disposal site from the municipality served can be argued regardless of time period or locality. The county sanitation districts of Los Angeles, as shown in Table 3 , are an example although the differentials quoted here are not necessarily indicative of those prevailing in other parts of the country. The Ascon landfill is situated at an average round trip haul of 13 miles from the City of Long Beach's refuse generation center and it is currently reaching capacity. Palos Verdes landfill requires a 26 mile round 
trip and will be filled by 1980. Puente Hills, at a 50 mile round trip distance from the waste generation center, will not be filled before the year 2000. But costs per ton of waste dumped are already high for this last facility as can be seen in Table 3 .

Table 3

Cost/ton of waste landfilled and landfill closure dates for the Los Angeles area.

$\begin{array}{ccc}\text { Site } & \text { Closure Date } & \text { Cost/ton }(1977 \text { dollars) } \\ \text { Ascon } & 1978 & 4.75 \\ \text { Palos Verdes } & 1980 & 5.60 \\ \text { Puente Hills } & 2000+ & 6.35\end{array}$

Source: Solid Waste Management Board: Bay Area Solid Waste Management Project, Phase 1, 1977.

\section{B. ENERGY BALANCES}

Energy balances for the three main garbage processing techniques as estimated by the Energy and Environment Division of the Lawrence Berkeley Laboratory (Ronald L. Ritschard et al., Draft 1978) are the following:

Table 4 Energy Efficiencies of Alternative Fuel Processes

\section{(1)}

Total $(2)$

Process

RDSF System/

Fuel Recovery

Direct Combustion

Pyrolysis

(Oil)

\section{Produced}

\section{(2)}

Used In

Process
(4) $\begin{array}{cc}\text { Net Energy } & \text { Recovery } \\ \text { Recovered Efficiency** }\end{array}$ Recovered Efficiency**

BTU/Ton of MSW Input*

$\begin{array}{llll}719 & 12 & 707 & 0.62 \\ 636 & 19 & 617 & 0.68 \\ 419 & 57 & 362 & 0.40\end{array}$

Note: $\operatorname{Col} \cdot 3=\operatorname{Col} \cdot 1-\operatorname{Col} \cdot 2 ; \operatorname{Col} \cdot 4=\operatorname{Col} \cdot 3 / 11.4 \mathrm{Million}$ $\overline{\mathrm{BTU}}$ per ton of MSW for RDSF and 9.1 Milizion BTU/ton for direct combustion and pyrolysis.

* Times 10,000.

**Energy Out/Energy In

Source: Ritschard, et al, 1978 (pp. 162, 170, 198).

Table 4 shows that direct combustion and RDSF are 
superior to pyrolysis in both recovery efficiency and net energy recovery. However, pyrolytic fuel is of a higher quality than those produced by the other processes. process is of high quality.

\section{QUALITY OF ENERGY AND POLLUTION PROBLEMS}

The quality of energy produced affects its marketability which, in turn, will inhibit or enhance the development of municipal waste processing techniques. The characteristics of RDSF depend on the composition of MSW which can vary over communities and seasons. Seasonal increase of moisture content in refuse can have a significant impact on the fuel value of RDSF unless it is dried and homogenized. The chemical constituents of RDSF are similar to those of coal as can be seen in Table 5. But the carbon content of RDSF is significantly lower than that of coal and this, together with moisture content, accounts for RDSF's low BTU value compared to coal. Coal and RDSF also differ in sulphur and oxygen contents. RDSF contains more oxygen but less sulphur than coal. Coal's higher sulphur content tends to make it a more polluting fuel than RDSF.

Table 5. Chemical Analysis of RDSF and Bituminous Coal (\%)

Component RDSF Bituminous Coal

$\begin{array}{lrr}\text { Carbon } & 28.35 & 69.70 \\ \text { Hydrogen } & 3.99 & 4.65 \\ \text { Nitrogen } & 0.53 & 1.40 \\ \text { Oxygen } & 20.79 & 6.25 \\ \text { Sulphur } & 0.17 & 4.00 \\ \text { Ash } & 16.17 & 11.50 \\ \text { Moisture } & 30.00 & 2.50 \\ & 100 & 100 \\ \text { Heat Value } & 4,620 & 11,500\end{array}$

Source: Overcoming Institutional Barriers to Solid. Waste Utilization as an Energy Source. Gordian Assoiate Inc., November 1977 .

From a pollution point of view, pyrolysis has significant advantages over other MSW energy recovery systems. Pyrolysis requires the addition of only small volumes of air and thus has a much smaller gaseous waste stream to deal with for emissions control. Moreover, in the case of gas producing systems, atmospheric emissions are eliminated.

Table 6 shows comparative stack emissions and waste 
water flows for the three main garbage processing techniques. Incineration is clearly the most polluting method. The major atmospheric pollutants emitted from large-scale incinerators are suspended particulates and carbon monoxide; on an equivalent heat input basis particulate emissions from burning refuse are considerably higher than from burning fuel oil or coal as can be seen in Table 7. Modular incinerators may prove to be less polluting. Currently, the Environmental. Protection Agency and the California State Solid Waste Management Board are conducting an analysis of the package incinerator facility in Little Rock Arkansas to determine its air and water emissions. This facility is considered to be the most advanced system of its type presently operating in the U.S. (Garretson, et al 1978b: 6).

Table 6 Air and Water Pollutants
Tons Per Trillion BTU Output
Method $\begin{array}{cc}\text { Water Air } \\ \text { Pollutants Pollutants }\end{array}$

Incineration

Fuel Recovery (RDSF)

Pyrolysis with Gas Production

$335(1)$

$17(3)$

$1720(5)$
$3626(2)$

$552(4)$

$1.2(6)$

Notes: (1) Includes suspended and dissolved solids, alkalinity, chlorides, hardness, sulfates and phosphates; (2) Includes particulates, SO2, NOx, CO, HCL, NH3 and acids; (3) Includes dissolved oxygen, biological oxygen demand, suspended solids, acid, phosphates, chromates, boron, organics, chloride and acid; (4) Includes particulates, SO2, NOx and Chloride; (5) Includes HCL, heavy metals and solubles; (6) Includes particulate from shredders.

Source: Characteristics of Solid Waste Conversion and Cogeneration Systems: Ronald L. Ritschard, Kendall F. Haven, William Walzer, Draft, July 1978 (pp. 45-46, 51-52). 
Table 7 Emissions In Pounds Per Million BTU Gross Heat Input Refuse (Incineration) Fuel 0 il

Bituminous Coal

Particulates

Sulphur Oxide

Carbon Monoxide

Hydrocarbon

Nitrogen Oxide

$\begin{array}{ll}3 & 0.05 \\ 0.25 & 1.15 \\ 3.5 & 0.02 \\ 0.15 & 0.01 \\ 0.3 & 0.7\end{array}$

Source: U.S. Environmental Protection Agency AP-42 in Overcoming Institutional Barriers to Solid Waste Utilization as an Energy Source, November 1977, Final Report (p. 167).

Sulphur dioxide emission from MSW burning is, however, lower than for either fuel oil or coal. But, a number of MSW processing plants report a particulate collection efficiency ranging from 93\%. (Braintree, Nashville) to $98 \%$ (Saugus).

Data on water pollution is scarce. According to Union Electric in St. Louis, one source of water pollution from RDSF processing and combustion is the surface runoff from washdown activities at the processing plant. This procedure involves relatively small quantities of effluent but the pollutant loadups of that effluent are high. As for pyrolysis, the pyrolysis gases contain acid gases, corrosive bars and oily substances which must be removed usually by wet scrubbing.

\section{MARKETING PROBLEMS}

The most marketable of the various MSW energy products is electricity. However, steam and methane are also valuable energy products.

Methane gas produced by the PUROX system is a medium BTU fuel that can be used directly in existing power plant systems that use natural gas. The only modification necessary is an increase in the inlet burner size because a greater volume of the fuel gas relative to natural gas must be burnt to obtain the same amount of heat (Table 8 ).

Among the factors to be considered in the use of pyroIysis gas as a utility fuel are its energy density, corrosive content, and the power required to compress the gas for pipelining. Problems with Methanol (pyrolytic oil) marketability are essentially related to its BTU value. 
Table 8 Comparison Between Refuse Derived

Gas and Natural Gas

Refuse Derived Natural Gas

Heating Value BTU/SCF (1)

Air required for Combustion Air/Gas
375

2.4

\section{(1) $\mathrm{SCF}=$ Standard Cubic Foot}

Source: Union Carbide in "Analysis of the California Energy Industry," 1977 Sathaye, et al (p. 147).

Electricity is a higher grade energy source than steam, steam's energy potential being dependant, in particular, on it's pressure. And, economic power transmission distances for electricity are high compared to transmission distance of other energy products. Consequently, where electricity is the main revenue producing product, refuse processing and power plant location can be almost entirely dictated by MSW collection logistics. But conversion of MSW to electricity is relatively inefficient compared to MSW to steam conversion. Efficiency ratio's (energy in/energy out) range from 12 to $30 \%$ for electricity production whereas they reach as much as $63 \%$ for steam production. Steam can be used directly for space heating and cooling or industrial process heating and as power for mechanical devices as well as for electric power generation.

As steam marketing, contrary to electricity, requires that customers be relatively close to the proposed generating facilities, a problem may arise if there is a residential area near to the industrial site. Moreover, potential clients would require reasonably regular service. As refuse is generated daily, and usually collected on a five day week basis, steam generation from MSW may have to be supplemented by fossil fuel generated steam.

But the above considerations remain theoretical since market conditions vary from one region to another for both economical and institutional reasons. For example, according to the Bay Area Solid Waste Management Project, (BASWMP) pyrolysis gas could have the highest potential market in California whereas RDSF has poor marketability prospects. But the lack of potential RDSF buyers stems from the fact that there are no coal fired facilities in the Bay Area and RDSF has historically been combusted in coal fired furnaces.

However, as BASWMP mentions, general market assessments for recovered products are based on information given by potential buyers before they have actually seen the products. Consequently, only reference to specific. MSW processing plants in operation can reveal precise information 
on energy saleability and value. Table 9 below gives minimum and maximum energy prices as quoted by various garbage processing plants.

Table 9 Price of MSW Derived Energy

\begin{tabular}{|c|c|c|c|}
\hline Steam & & $\begin{array}{l}\text { Minimum } \\
\text { (Braintree MA) }\end{array}$ & $\begin{array}{l}\text { Maximum } \\
\$ 5.88 / 1,0001 \mathrm{bs} \\
(\text { Nashville TN) }\end{array}$ \\
\hline Electricity & Peak & $\begin{array}{l}1.9 \text { cent } / \mathrm{kwh} \\
(\text { Haverhill MA) }\end{array}$ & $\begin{array}{l}3.2 \text { cent/kwh } \\
\text { (Middlesex County } \mathrm{NJ})\end{array}$ \\
\hline Electricity & Off Peak & -- & 1.6 cent $/ \mathrm{kwh}$ \\
\hline $\begin{array}{l}\text { RDSF } \\
\text { (Utility } q\end{array}$ & uotes) & 1.72\$/Ton & $5.72 \$ /$ Ton \\
\hline
\end{tabular}

Source: Overcoming Institutional Barriers to Solid Waste Utilization as an Energy Source, Gordian Associates, Inc., 1977, Final Report (pp. 130-133).

Customers for MSW derived energy are primarily the utilities. The utilities generally require a test period, and the price of energy depends on the cost to utilities of displaced coal or oil. In most cases the utility does not make a long term commitment until the test requirements have been satisfied. The general trend is for utilities to be more willing to purchase MSW based electricity and, in specific instances, steam and these at widely variying prices as can be seen on Table 9. Utilities are reticent when it comes to purchasing RDSF and in some instances have insisted upon retaining the ability to terminate RDSF use at any time if, in their judgement, unit reliability is impaired.

III. MECHANICAL VERSUS HOME SEPARATION OF RECYCLABLES

\section{A. INTRODUCTION}

The chief function of garbage processing facilities is to produce a fuel product from the combustible portion of MSW. But these plants also have the option of installing equipment. which will recover valuable scrap materials from the heavy, noncombustible fraction of MSW. While this mechanical recycling is a secondary activity, it can serve two important functions: it reduces the amount of unusable residue which must otherwise be disposed of at a generally high cost, and it provides revenue which helps to offset the costs of the facility.

This subsection examines the compatibility of this form 
of recycling -- through mechanical means at a centralized garbage processing facility -- with separate collection of the recyclable materials through a community pick-up program. To examine these components, hypothetical cases were postulated for the two systems. These were compared according to relative efficiencies in recovery, energy savings and the costs associated with each approach.

\section{B. POTENTIALLY RECOVERABLE MATERIAL}

For both mechanical and source separation systems, the potential recoverable newsprint, glass, ferrous metals and aluminum were taken to be the average of the total amounts of these recyclables found in municipal garbage as reported by numerous studies in Table 10. For the sake of comparison, the purity of these materials was assumed to be comparable. In fact, materials recovered mechanically may, in some instances, be highly contaminated, a qualifying consideration which will be discussed in the subsection on cost considerations.

Table 10. RECYCLABLES IN THE WASTE STREAM

( $\%$ OF TOTAL MSW)

Source Newsprint Glass Steel/Alum Total

Sunset Scavengers

$$
1978
$$

MRI 1974

EPA 1977

Ritschard 1978

Garretson, et al

1978

Mathematical

Sciences 1974

BAYSMP 1977

Average

8
7
6

12

10

9

9

13
8
10
10

$8 / 1$

$8 / 1$

$8 / 1$

$8 / 1$

11

\section{8}

9 .

10
31

24

25

29

$24 \cdot 5$

26

27

The mechanical recovery system was assumed to be a best case example where aluminum, ferrous metals and glass were recovered at the average levels reported by several operating facilities (Table 11). The recovery efficiency of newsprint, as a portion of the resulting fuel, was assumed to be $95 \%$ of the amount available in MSW (General Electric 1975: 79 ).

Determining the comparable recovery levels for a source separated program that collected newspapers, glass and metals presented several difficulties, since the recovery levels of these materials is highly dependent upon 
community-specific factors. The importance of two of these factors, education and affluence, is illustrated by the examples of Somerville and Marblehead, Massachusetts. These nearly adjacent cities have similar source separation programs which have been under intensive study by the Environmental Protection Agency. In Somerville where the average income is $\$ 9,600$ and the median educational level is 11.6 years, the recovery level for recyclables is $5 \%$. In Marblehead, where the average income is $\$ 12,600$ and the median education level is 13.2 years, $25 \%$ of the recyclables are being recovered, a five-fold increase (Resource Planning Associates 1978: 1.1). Participation in source separation has also been shown to rise with lengthening program duration (Environmental Protection Agency 1976: 47). Other influencing factors include the frequency of collection, prior community experience with recycling and the educational efforts of the program sponsors.

Table 11. MECHANICAL SEPARATION RECOVERY LEVELS (\% OF TOTAL MSW)

\section{Source Glass Steel Alum Total}

$\begin{array}{lcllr}\text { Occidental } & 5.3 & 6.7 & .4 & 12.4 \\ \text { Black Clausen } & 6.0^{*} & 6.5 & .8 * & 13.5 \\ \text { Combustion Power } & 3.0 & 5.0 & .5 & 8.5 \\ \text { Garret Pyrolysis } & 5.6 & 6.6 & & 12.2 \\ \text { Monsanto } & -- & 6.7 & & 7.4 \\ \text { Americology } & 5.7 & 7.0 * & .5 & 13.2 \\ \text { St. Louis } & -- & 6.7 & -- & 6.7 \\ & & & & \\ \text { Averages: } & 5.1 & 6.6 & .6 & 12.3 \\ \text { Recovery } & & & & \\ \text { Efficiency*: } & 51 & 94 & 60 & 46\end{array}$

* Recovery Rate (\%) / Resource in MSW (\%)

Source: General Electric 1975, Lidstrum 1974, Preston 1976.

To arrive at average recovery levels for a recycling pick-up model, the experience of several programs were surveyed, as shown in Table 12. In this table, the reported participation levels were generally determined by dividing the number of set-outs by the number of households in the community. Recovery levels were calculated by dividing the tonnage collected for each material by the total amount of the material available in the local MSW stream. This latter amount was based upon the average percentages for the recylable materials shown in Table 10, with the exceptions of the 
New York City area programs where the newsprint fraction was assumed to be a higher-than-average $12 \%$ of MSW.

Table 12. SOURCE COLLECTION EFFICIENCIES

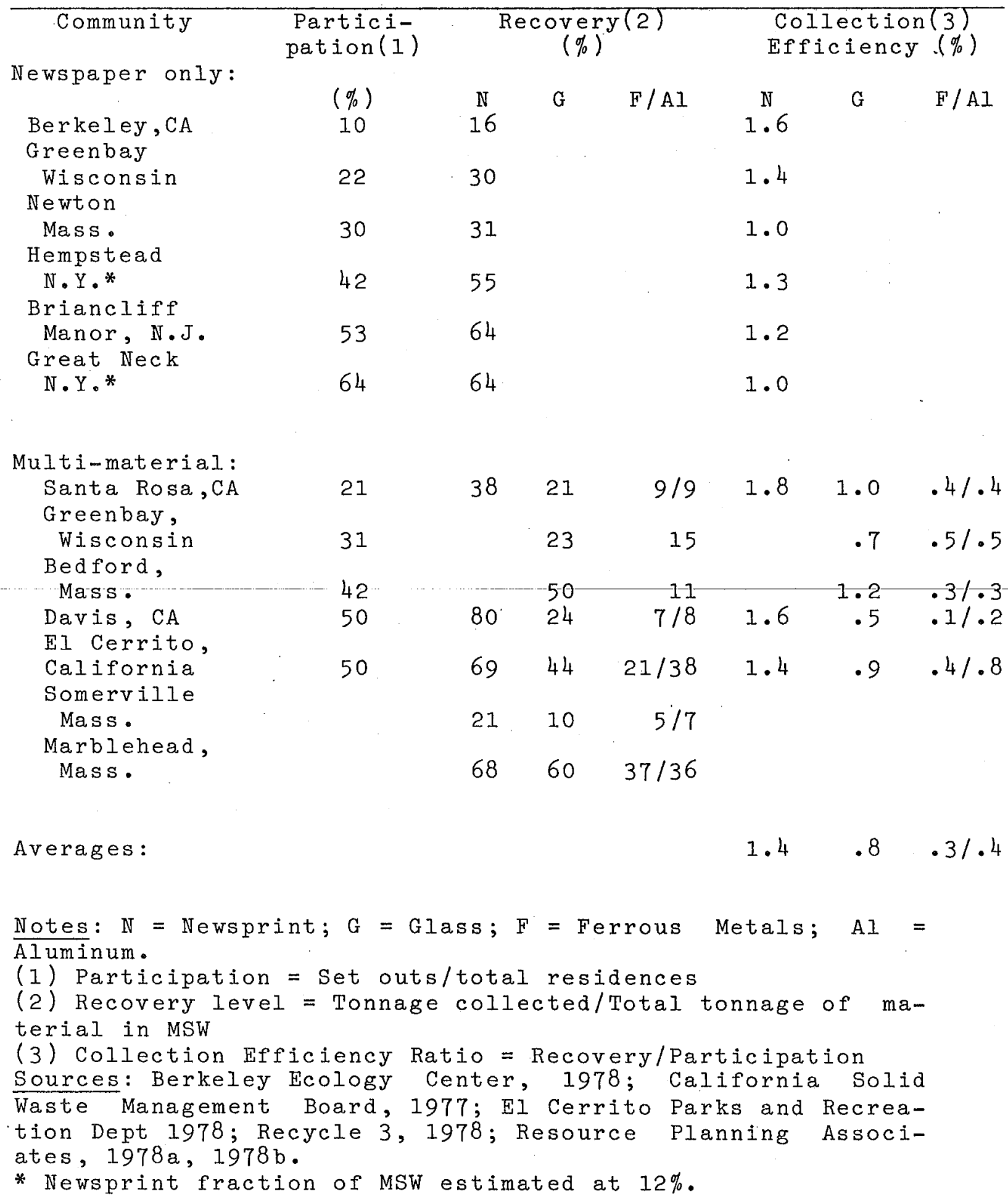


Two "best case" source separation programs were then postulated: one at $40 \%$ participation within the community and a second at a $60 \%$ participation level. Both are levels presently being experienced by the existing programs in Table 12. The recovery levels associated with these participation levels were determined by multiplying $40 \%$ and $60 \%$ times the average "Collection Efficiency Ratios" or CERs for each recyclable material. The CER is simply the recovery level for each material divided by the reported participation level; it provides a useful means of comparing the effectiveness of recycling efforts among different programs.

A CER below 1.0 was taken to mean that participating residents were providing the program with only a portion of the recyclables they consume. However, this assumption holds true only when the materials are uniformly consumed and recycled within the community. While this is most likely the case for glass and metals, it is not the situation for newsprint which is distributed unequally in the community. Some households, for example, may subscribe to more than one newspaper, while others may not subscribe to any. In general, we can expect that the more educated and affluent sectors of the community will be consuming a disproportionate share of total newsprint. As the Somerville and Marblehead studies have suggested, this is also the sector which is most likely to participate in a recyling program. As a result, we can expect that newspaper recovery levels can easily exceed the levels of participation, producing CERs above 1.0. This is in fact the case in Table 12 where the average CER for newsprint is 1.4. Though not reflected in the sample of programs surveyed, it can be assumed that the initially high recovery level for newsprint will taper off at higher participation levels, reflecting a steady decline in the availability of newsprint in the community. For that reason, the $1.4 \mathrm{CER}$ was chosen for the participation levels up to $50 \%$, after which it was assumed to decline to a CER of .6 .

Glass and the metals, on the other hand, were assigned constant recovery levels at $40 \%$ and $60 \%$ participation levels. The average CER for glass is .8 which means, in effect, that each participating household is recycling $80 \%$ of its glass containers. The metals are the least efficiently recovered, most likely because steel food cans require cleaning and flattening, and because aluminum containers are already being efficiently recycled by the public. The average recovery level for aluminum nationwide is $25 \%$; in California, it is 40\% (Reynolds Aluminum 1978). The majority of this aluminum is collected not by source separation programs, but by individuals and organizations who are attracted by the high market value of the metal and by the successful publicity campaigns of the large aluminum producers. 
The metals also posed the largest uncertainty since most of the programs failed to differentiate between aluminum and ferrous metals recovery. The distinction is critical because of the high energy savings attributable to aluminum recovery and because of its high revenue value already alluded to. The evidence from those programs which did differentiate the two metals, however, suggests that the proportion of aluminum to steel in MSW remains constant in recycling. The resulting CERs were therefore assumed to be - 3 for steel and . 4 for aluminum. It was further assumed that the total recovery of aluminum in the community, of which a source separation program contributed a part, would be $25 \%$ in a medium participation scenario $(40 \%)$ and $40 \%$ in a high participation scenario $(60 \%)$. This means that, even in the absence of a source separation program, only $75 \%$ and $60 \%$ of the aluminum in $M S W$ is made available for mechanical recovery at a garbage processing facility at these scenario levels.

Table 13 shows that from a strictly materials recovery comparison, the $60 \%$ source separation scenario can be expected to recover about the same amount of glass, slightly less aluminum and considerably less ferrous metals than a mechanical recovery system. More newsprint can be recovered in a resource recovery facility than through even a high participation source separation program. As shown in Tables $13 \mathrm{a}$ and $13 \mathrm{~b}, 95 \%$ of the available newsprint in MSW is recovered for use as a fuel. This compares to $56 \%$ recovery for a medium participation scenario ( $40 \%$ participation) separation scenario and $76 \%$ recovery in a high participation scenario ( $60 \%$ participation).

Table 13. COMPARATIVE MATERIAL RECOVERY EFFICIENCIES (POUNDS PER TON OF MSW)

\begin{tabular}{|c|c|c|c|c|c|c|}
\hline Material & $\begin{array}{l}\text { Source } \\
\text { @ } 40 \%\end{array}$ & $\begin{array}{c}\text { Recovery } \\
060 \%\end{array}$ & No & $\begin{array}{l}\text { Mechanical } \\
\text { Recycling }\end{array}$ & $\begin{array}{l}\operatorname{Recov} \\
040 \%\end{array}$ & ry \\
\hline News & 100 & 140 & & 1.72 & 76 & 38 \\
\hline Glass & 60 & 100 & & 102 & 72 & 52 \\
\hline Ferrous & 16 & 24 & & 132 & 116 & 108 \\
\hline Aluminum & 4 & 6 & & 8 & 8 & 7 \\
\hline Totals & 180 & 270 & & 414 & 272 & 205 \\
\hline Efficiency* & $33 \%$ & $50 \%$ & & $78 \%$ & $52 \%$ & 56 \\
\hline
\end{tabular}

*Efficiency $=$ Amount of collected recyclables/Total recyclables in MSW of $540 \mathrm{lbs} / t o n$ (derived from Table la). 


\section{POTENTIALLY RECOVERABLE ENERGY}

The amount of energy that can be saved through recycling ranges from 2.1 million BTU/ton for glass cullett used to replace virgin materials in glass manufacturing ( $15 \%$ savings), to 235 million BTU/ton for using aluminum scrap in place of virgin ore - a 95\% savings. These savings, presented in Table 1.4, are subject to some variation depending upon regional markets and the quality of the materials recovered. For example, the glass energy savings result from re-melting into containers, the most common end use of both color-sorted and mixed cullet in California. However, the glass recovered through some mechanical separation systems is presently so highly contaminated that it can be used only for road construction in which case the energy savings are negligible. Similarly, steel cans recovered on the West Coast are frequently sold to copper mines where they serve as precipitation agents, again with little meaningful energy recovery.

Table 14: Potential Energy Savings - Source Separation

Material Energy Use Energy Savings

\begin{tabular}{lccccccr} 
& $\begin{array}{l}\text { Virgin } \\
(\mathrm{E} / \mathrm{tm})\end{array}$ & $\begin{array}{c}\text { Recycling } \\
(\mathrm{E} / \mathrm{tm})\end{array}$ & $\begin{array}{c}40 \% \\
(\mathrm{E} / \mathrm{tm})\end{array}$ & $\begin{array}{c}60 \% \\
(\mathrm{E} / \mathrm{tMSW})\end{array}$ & $\begin{array}{c}40 \% \\
(\mathrm{E} / \mathrm{ct})\end{array}$ \\
\hline News & $17.0(1)$ & $5.0(1)$ & 12.0 & .6 & .84 & 6.7 & 6.2 \\
Glass & $13.6(2)$ & $11.5(3)$ & 2.1 & .06 & .11 & .7 & .8 \\
Ferrous & $24.0(4)$ & $8.5(5)$ & 15.5 & .12 & .19 & 1.4 & 1.4 \\
Aluminum & $244.0(4)$ & $8.7(5)$ & 235.0 & .5 & .71 & 4.7 & 4.7 \\
TOTALS & & - & - & 1.28 & 1.85 & 13.5 & 13.1 \\
\hline
\end{tabular}

$\mathrm{E} / \mathrm{tm}=$ Million $\mathrm{BTU} / \mathrm{ton}$ of material

$\mathrm{E} / \mathrm{tMSW}=$ Million BTU/ton of MSW

$\mathrm{E} / \mathrm{ct}=$ Million BTU/collected ton

Sources:

1) Midwest Research Institute, 1972

2) California State Solid Waste Management Board, 1978

3) Glass Container Corporation, 1978

4) Battelle, 1978

5) A. D. Little, 1978

It was assumed that the materials recovered from source separation programs and mechanical separation equipment were marketed for the ideal re-use upon which the calculations in Table 14 are based. With this the case, the comparative energy savings for glass and metals parallels the materials recovery figures shown in Tables 13a and 13b: source separation results in less energy savings than mechanical 
recovery, primarily because the latter can recover ferrous metals with very high efficiency ( $94 \%)$.

Newsprint again must be examined separately because of the different end uses of this material in each recovery system. A ton of recycled newsprint used to replace virgin material in paper production saves 12 million BTU per ton. Used as a fuel, newsprint begins with a heating value of around 16 million BTU (Mathematical Sciences 1974: III-31), but loses considerable amounts of this potential through conversion inefficiencies in the different fuel processes. A facility which produces steam from RDSF, for example, is the most efficient fuel conversion system, yet it only converts $63 \%$ of the heat value of its MSW fuel to usable energy. The least efficient fuel conversion system uses MSW to make electricity and has an efficiency of 22-24\% (Ritschard 1978). On a ton per ton basis, therefore, recycled newsprint saves $2-8.5$ million BTU more energy than newsprint used as fuel.

Table 15 compares these two end uses of newsprint on a more relevant basis of the energy savings per ton of MSW, which takes into account the recovery efficiencies of the different systems. On this basis, recycled newsprint still outranks all or most fuel conversion systems: in a high participation scenario, it ranks first, while at a medium level of participation the energy savings per ton of MSW are higher than any fuel recovery process except RDSF to steam. Another key question is the impact that prior recycling will have on the fuel value of MSW. Table 16 shows that the reduction of newsprint in MSW by recycling lowers the heat value of the MSW fuel, though only by $7-10 \%$.

Table 15: Comparative Energy Savings For Newsprint Recovery*

Energy Conversion Efficiency No Prior Process $(\%)$ Recycling @40\% @60\%

Mechanical Separation:

MSW-RDSF-Steam

MSW-Steam ( D.C.**)

Pyrolysis Oil

MSW to Elec (D.C.)

MSW to Elec (RDSF)

MSW to Elec (OiI)

Source Separation
63

56

37

29

24

22
.74
.66
.43
.33
.29
.26

$-$
.33

.29

.19

.15

.13

.12

$.59 \quad .83$

*Million BTU/ton MSW

**Direct Combustion

Source: Ritschard, 1978 
Table 16: Potential Heat Value of Newsprint and MSW Fuel

Newsprint(1) Total Fuel(2) Change (MM BTU/ton of MSW)

\begin{tabular}{lrrr} 
No Prior Recycling & 1.20 & 9.36 & - \\
$40 \%$ Participation & .53 & 8.69 & 7 \\
$60 \%$ Participation & .27 & 8.43 & 10 \\
\hline
\end{tabular}

1) Assumes: Newsprint heat value of 16 million BTU/ton and 95\% recovery of newsprint.

2) Assumes: MSW Fuel valve of 11.7 million BTU/ton and. 8 tons of fuel per ton of MSW.

Table 17: Comparative Energy Savings

for Multi-Materials Recovery

No Prior Recycling @40\% @60\%

(MM BTU/ton of MSW)

Mechanical Recovery(1):

\begin{tabular}{lcrr} 
MSW-RDSF-Steam & 3.62 & 3.22 & 3.07 \\
MSW-Steam (D.C.)* & 3.54 & 3.18 & 3.05 \\
Synthetic Oil & 3.31 & 3.08 & 2.99 \\
MSW to Elec (D.C.)* & 3.21 & 3.04 & 2.97 \\
MSW to Elec (RDSF) & 3.17 & 3.02 & 2.96 \\
MSW to Elec (Oil) & 3.14 & 3.01 & 2.95 \\
Source Separation(2) & - & 1.25 & 1.81 \\
\hline
\end{tabular}

*D.C. = Direct Combustion

1) Adjusted for conversion efficiencies and process energy.

2) Adjusted for fuel energy use in collection.

Table 17 combines the previous two tables in a summary comparison of the energy savings for all recycled materials. It is important here to consider the two systems as potentially compatible. A high participation source separation program, in this respect, could be seen as a pre-processing step for an RDSF system which also recovered ferrous metals. The resulting savings in this case would be much higher than either source separation or fuel and ferrous metals recovery considered separately.

The figures in this table have been slightly adjusted to account for the energy consumed in the processing of the materials. For source separation recovery, this energy consisted of fuel used to operate the collection vehicles. 
While comprehensive data on miles travelled per ton of collected material is lacking, an average was obtained based on the experience of several California programs. From this sample, we can tentatively conclude that the energy use per ton of MSW for source separation appears to be quite small, around $1-2 \%$ of the energy that is ultimately recovered by recycling the materials (Table 18 ).

Table 18: Energy Use for Mechanical Processing and Recovery of MSW

Process

Energy Use
BTU/Ton of MSW (Thousands)

Front End:

Shredder

64

Air classifier $\quad 31$

Subtotal $\quad 95$

Materials recovery:

Ferrous

Aluminum

Glass

Subtotal

Total:

SOURCES: Portland Recycling Team-1-975: 100; Institute-of Gas Technology 1976: 92 .

For garbage processing plants, the energy used to process the materials consists of electricity for equipment operation. This equipment energy use was broken into two categories: the front end processing which separates the fuel or light fraction, and the heavy fraction processing which separates the recyclable glass and metals. The front end energy use amounts to about 1 million Btus/ton of incoming MSW, assuming the use of 1,000 horsepower hammermill processing 40 tons/hour and a suitably sized air classifier (Portland Recycling Team 1975: 100). This energy use was subtracted from the final energy value of the fuel.

After its initial separation, the heavy fraction may go through a series of mechanical processes to extract the recyclable ferrous, aluminum and glass. Using figures derived from the Occidental plant, the approximate use for these processing steps is 40,000 Btus/ton of MSW (Institute of Gas Technology 1976:92). Table 18 summarizes the approximate breakdown of energy use within a resource recovery facility. Again the figure is small, around $1-3 \%$ of the total energy saved. 
Table 19: Energy Consumption in Materials Collection*

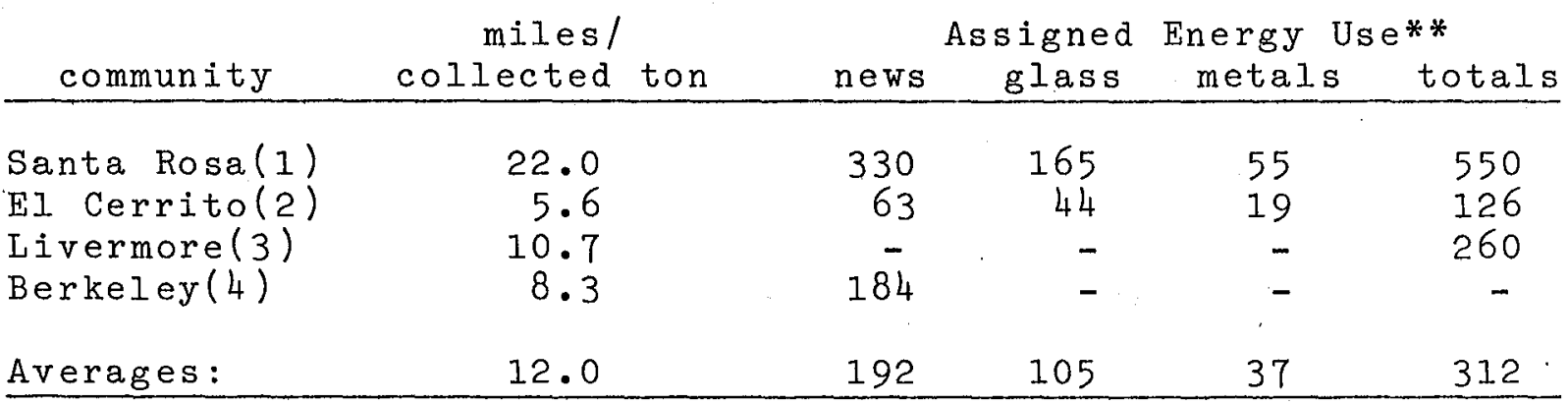

*at $5.5 \mathrm{mpg}$ and $122,000 \mathrm{BTU} / \mathrm{galion}$

* *Thousand BTU/collected ton

Sources :

1) Recycle 3, 1978

2) EI Cerrito Parks and Recreation, 1978

3) Livermore Disposal Company, 1978

4) Berkeley Ecology Center, 1978

D. COST CONSIDERATIONS

1. Cost of Source Collection

As with resource recovery facilities, costs for source separation programs can be highly specific to each community. They are dependant upon prevailing wages, types of vehicles used, market conditions, overhead, financing considerations and the cost of current disposal.

The most cost effective source separation programs have been those which have collected only newsprint. Even in such high cost areas as San Francisco, where collectors receive $\$ 24,000$ annually, newsprint collection has proved to be a profitable enterprise. Table 20 shows how newspaper collection programs using separate trucks have generally lowered the overall garbage collection costs during favorable market conditions. When existing collection trucks are specially equipped with racks, as shown in Table 2l, the reduction savings are realized even when paper prices are at a low \$8/ton, in 1974 dollars. 
Table 20. TOTAL MSW COLLECTIOM COST IMPACT OF SEPARATE PAPER PICK-UP

Community

Dallas, TX

Fort Worth, TX

Great Neck, NY

Green Bay, WI

Greenbelt, $M D$

Marblehead, MA

Newton, MA

University $\mathrm{Pk}$, TX

Villa Park, IL

W. Hartford, CN
Collection and Disposal Costs ( $\$ /$ ton)

$$
\text { Original }
$$

After Pick-Up Program

@ $\$ 8 / \operatorname{ton}$

Cost $\%$ Change Cost $\%$ Change

$\begin{array}{lllll}12.10 & 11.60 & -4.1 & 9.3 & -23.1 \\ 13.50 & 14.1 & +4.4 & 11.80 & -12.6 \\ 36.00 & 38.70 & +7.5 & 36.50 & +1.4 \\ 38.70 & 37.70 & -2.6 & 37.10 & -4.1 \\ 27.20 & 27.40 & +0.7 & 26.30 & -3.3 \\ 23.10 & 25.30 & +9.5 & 24.10 & +4.3 \\ 32.40 & 32.20 & -0.6 & 31.60 & -2.5 \\ 14.70 & 14.90 & +1.4 & 13.10 & -10.9 \\ 13.50 & 13.40 & -0.8 & 12.40 & -8.1 \\ 26.30 & 26.50 & +0.8 & 25.20 & -5.7\end{array}$

Source: SCS Engineers, Analysis of Source Separate Collection of Recyclable Solid Waste; Separate Collection Studies, 1974, in Decision Makers Guide in Solid Waste Management 1976 .

Table 21. TOTAL MSW COLLECTION COST IMPACT RACK METHOD OF PAPER PICK-UP

\begin{tabular}{|c|c|c|c|c|c|}
\hline \multirow[t]{2}{*}{ Community } & \multicolumn{2}{|c|}{$\begin{array}{l}\text { Collection } \\
\text { Original }\end{array}$} & $\begin{array}{l}\text { and Disposal } \\
\text { After Separat } \\
\text { @ } \$ 8 / \text { ton }\end{array}$ & \multicolumn{2}{|c|}{$\begin{array}{r}\text { Costs Per Ton } \\
\text { e Collection } \\
\text { @ } \$ 25 / \text { ton }\end{array}$} \\
\hline & & Cost & $\%$ Change & Cost & $\%$ Change \\
\hline Madison, WI & $22 \cdot 30$ & 22.00 & $-1 \cdot 3$ & $20 \cdot 50$ & $-8 \cdot 1$ \\
\hline New York, N.Y. & $53 \cdot 50$ & 53.40 & -0.2 & $53 \cdot 50$ & 0 \\
\hline Sheboygan, WI & 32.00 & 31.80 & -0.6 & 31.50 & $-1 \cdot 6$ \\
\hline
\end{tabular}

Source: SCS Engineers, Analysis of Source Separate Collection, 1974. In Decision-Makers Guide in Solid Waste Management, 1976.

Another important cost consideration is the capacity of the community to utilize existing resources from the regular garbage pickup program for the recyclables collection program. A clear illustration of this is shown in Table $22 a$ for the communities of Somerville and Marblehead, Massachusetts. In Somerville, the full costs of a source separation program is around $\$ 80$ per ton of collected recylables in 1977. However, because the city was able to transfer six workers from the original refuse program to the recycling program, the actual costs to the community was $\$ 36$ 
per ton. Similarly, in Marblehead, the full costs of the program to collect recyclables would have been $\$ 13$ per ton, except that the city was able to transfer several crew members and one vehicle from the original refuse program. As a result, the Marblehead program actually earned $\$ 10$ per ton profit in 1977. These costs, of course, represent the recovery levels of the two communities which were $5 \%$ in Somerville and $25 \%$ in Marblehead. They also represent local market conditions and disposal costs. The latter are moderately $\mathrm{high}$ in Somerville ( $\$ 9.40 /$ ton) and very $\mathrm{high}$ in Marblehead ( $\$ 18.95 /$ ton) (Resource Planning Associates $1978 \mathrm{~b}$ : 1.2).

Table 22a. Source Separation Collection Costs Somerville and Marblehead, Massachusetts ( $\$ /$ ton)

Community

Unsorted Garbage Pick-Up Costs

Recyling Cost/Revenues

Full Costs of Recycling
Actual Costs of Recycling
Somerville

( $5 \%$ Recovery)

Marblehead

( $25 \%$ Recovery)
$-24$

$-31$
$-79$

$-13$
$-36$

$+10$

Source: Resource Planning Associates 1978b.

To arrive at a general range of costs for California, several source separation projects were surveyed. The results are shown in Table $22 \mathrm{~b}$. The communities included one rural city where recycling is mandatory (Davis), an urban-impacted city (El Cerrito) and a newspaper-only pickup program (Berkeley). These are compared with a "high cost" program which was based on estimates provided by the sunset Scavenger Company of San Francisco where the terrain and high wages were the chief cost escalators. The costs are adjusted to reflect credit from an average disposal charge of $\$ 6$, taken from Table 23 and projected materials recovery revenue shown in Table 24. Revenue/ton was based on longterm market prices recently projected for the city of Berkeley, California by the consulting firm of Garretsen, Elmendorf, Zinov \& Reiben. They are believed to be representative prices for the remainder of the state.

While additional information should be sought for other communities, Table $22 \mathrm{~b}$ does indicate that none of the multi-materials programs surveyed can be expected to meet expenses based upon the projected revenue and recovery rates at $40 \%$ and $60 \%$ participation levels. It should be noted, however, that these costs are substantially lower than the 
collection costs for unsorted garbage as reported in Table 20 .

Summary Table 25 compares the revenue/ton of MSW of source separation programs with revenues derived from mechanical separation. Because of current market uncertainty, not included under mechanical separation are the revenues derived from the newsprint portion of the MSW fuel. By th this reckoning, the highest revenue/ton of MSW accurs at a $60 \%$ source separation participation level, followed by mechanical separation with only aluminum recycled prior to arrival of the MSW at the facility.

Table 22b. Source Separation Collection Costs California Examples

(Dollars/ton)

\begin{tabular}{lccc}
\multicolumn{1}{c}{ Community } & Gross Costs & \multicolumn{3}{c}{ Net Costs/Revenues* } \\
& & $40 \%$ & $60 \%$ \\
\hline Davis(1) & 48 & -16.50 & -13.50 \\
El Cerrito(2) & 45 & -13.50 & -10.50 \\
Berkeley(3) & 26 & +3.0 & +3.0 \\
High Labor(4) & 119 & -87.50 & -84.50 \\
\hline
\end{tabular}

*Includes landfill credit and revenue for sale of materials.

Sources:

1) Davis Waste Removal Company, 1978

2) El Cerrito Parks, Recreation and Recycling Department, 1978

3) Berkeley Ecology Center, 1978

4) Based on Cost Data from Sunset Scavengers Company, San Francisco 
Table 23. Disposal Costs (Dollars/Ton)

\begin{tabular}{lrc}
\multicolumn{1}{c}{ City } & Present Costs & $1980-1990$ Costs \\
\hline San Francisco & 14.30 & 16.00 \\
Davis & 3.25 & $*$ \\
Contra Costa & 3.00 & 3.00 \\
Alameda & 2.80 & 11.00 \\
Humboldt & 6.00 & $*$ \\
Los Angeles & 5.60 & 8.35 \\
San Diego & 5.60 & 5.80 \\
Santa Rosa & 6.00 & $*$ \\
Average: & $\$ 6.00$ & $\$ 9.00$ \\
\hline
\end{tabular}

*Information not available.

Sources: Refuse to Energy Conversion Projects, 1977; Davis Waste Disposal Service, 1978; Sunset Scavengers, 1978;

Table 24: Projected Revenue -- Source Separation Material Price(1) Amount in Collected
Tons of Recyclables (\%) (\$/ton)

Revenue

( $\$ /$ collected ton) $040 \% \quad 060 \% \quad 040 \% \quad 060 \%$

\begin{tabular}{lrrrrr} 
News & 23 & 45 & 44 & 10.35 & 10.10 \\
Glass & 13 & 36 & 38 & 4.70 & 4.95 \\
Aluminum & 340 & 2 & 3 & 7.40 & 10.20 \\
Ferrous & 20 & 5 & 16 & 3.00 & 3.20 \\
& & 100 & 100 & 25.50 & 28.50 \\
\hline
\end{tabular}

1) Garretson, Elmendorf, Zinov and Reiben, 1978a, page 30 .

Table 25: Revenue From Recycling Alternatives (\$/ton)

\begin{tabular}{|c|c|c|c|c|c|}
\hline & \multirow{2}{*}{$\begin{array}{c}\text { Source } \\
40 \%\end{array}$} & \multirow{2}{*}{$\begin{array}{c}\text { Separation } \\
60 \%\end{array}$} & \multicolumn{3}{|c|}{ Mechanical } \\
\hline & & & $\operatorname{Rec}$. & $40 \%$ & $60 \%$ \\
\hline News & 1.45 & 2.03 & - & - & - \\
\hline Glass & .57 & .95 & .97 & .68 & .50 \\
\hline Ferrous & .21 & .31 & 1.72 & 1.51 & 1.41 \\
\hline Al uminum & .69 & 1.04 & 1.43 & 1.43 & 1.16 \\
\hline Totals & 2.82 & 4.33 & 4.12 & 3.62 & 3.07 \\
\hline
\end{tabular}




\section{Costs of Mechanical Recovery}

The costs of recovering ferrous, glass and non-ferrous materials through mechanical separation is the sum of the amortized capital costs for the necessary equipment and its operating costs. One source for the capital costs for recovery equipment at a 1,000 tons/day facility can range from $\$ 620,000$ for a scaled up version of Combustion Power Corporation's present test facility to $\$ 1,690,000$ for a hypothetical system designed by General Electric (General Electric 1975:325). The breakdown for this latter estimate is shown in Table 26.

Table 26: Capital Costs for Materials Recovery Equipment

Equipment

Magnetic Separation

Ferrous Metal shearing

Subtotal Ferrous Recovery

Glass Separation

Non-magnetic Screening

Subtotal Glass Recovery

Aluminum separation

Total

$$
\$ 1000^{\prime} \mathrm{s}
$$

150

300

470

160

630

45

470

34

$\%$ of Total

1400 100

Source: General Electric 1975, page 325.

Unfortunately, reliable data for the operational costs of material recovery systems are sparse, particularly for glass and aluminum recovery systems which have been plagued with technical difficulties (Levy,et al 1976: 76,78). On the other hand, ferrous recovery systems have proven to be reliable and extremely cost effective, as illustrated in Table 27 for a 1,000 ton/day A.M. Kinney process. In this case, the additional $\$ 80,000$ in equipment, insurance and annual operating costs are more than compensated by $\$ 288,000$ in annual revenue and landfill credit. 
Table 27. COST ESTIMATES ADJUSTED FOR FERROUS METAL RECOVERY FOR A.M. KINNEY PROCESS (1975 Figures)*

\begin{tabular}{|c|c|}
\hline Cost & Amount \\
\hline $\begin{array}{l}\text { Costs for Magnetic } \\
\text { Recovery Equipment }\end{array}$ & 50,000 \\
\hline $\begin{array}{c}\text { Increased Operating Costs } \\
\text { With Ferrous Recovery }\end{array}$ & 25,000 \\
\hline $\begin{array}{l}\text { Increase In Amortization } \\
\text { And Insurance }\end{array}$ & 5,000 \\
\hline Total Annual Costs & 80,000 \\
\hline $\begin{array}{l}\text { Revenue From Sale of } \\
\text { Metal ( } 65 \text { tons/day, } \\
\$ 10 / \text { ton) }\end{array}$ & 240,000 \\
\hline $\begin{array}{l}\text { Reduced Landfill Cost } \\
(65 \text { tons/day, } \$ 2 / \text { ton })\end{array}$ & 48,000 \\
\hline Total Annual Revenue & 288,000 \\
\hline Net Annual Revenue & 208,000 \\
\hline
\end{tabular}

Source: General Electric 1975.

* Based on a 1,000 ton/day facility and 365 days/year; Net costs will rise considerably for a shorter work year.

While the technical difficulties associated with glass and aluminum mechanical recovery may be ultimately resolved, for the meantime they result in uneven quality for the recovered material. Some recovery facilities, for example, are only able to produce a glassy aggregate which has limited marketability; likewise mechanically separated aluminum is often highly contaminated when compared to source collected aluminum.

Another revenue consideration is the possibility of passage, on either a state or federal level, of a beverage deposit law. Since most of the aluminum in MSW consists of beverage cans, such legislation makes investment in costly equipment to recover aluminum appear unwise at this time. 
IV. BIBLIOGRAPHY

A. D. Little

1978 Study of Energy Use Patterns for Recycling. In NARI Eco-Technic News (\#10, March, 1978). N.Y., N.Y.: National Association of Recycling Industries.

Anderson, Kent et al

1976 Decision-Makers Guide in Solid Waste Management. Washington, D.C.: U.S. Environmental Protection Agency

Assembly Committee on Labor, Employment \& Consumer Affairs 1977 Survey of Garbage Rates in the State of California. Sacramento, California: State Legislature.

Battelle Columbus Laboratories

1978 Energy Use Patterns in Metallurgical and Non-Metal Mineral Processing. In NARI Eco-Technic News (\#10, March, 1978). N.Y., N.Y.: National Association of Recycling Industries.

Berkeley Ecology Center

1978 Berkeley Newspaper Pick-Up Program: Monthly Reports on Revenue, Tonnages and Expenses, 1977. Berkeley, California: Ecology Center (unpublished).

California Resource Recovery Association

1978 Reduce, Reuse, Recycle Proceedings of CRRA Yosemite Mini-Conference, October, 1977. Santa Barbara, California: CRRA

California State Solid Waste Management Board

1977 a Bay Area Solid Waste Management Project - Phase 1. Sacramento, California: CSWMB.

California State Solid Waste Management Board

1977b Refuse to Energy Conversion Projects. Sacramento, California: California State Solid Waste Management Board.

California State Solid Waste Management Board

1976 Resource Recovery Program, Volume II, Unabridged Report Sacramento, California: CSWMB

California State Solid Waste Management Board

1978 Energy Analysis of Secondary Material Use in Product Manufacture, Progress Report 1, Energy Consumption in Manufacturing Glass Containers without Use of Secondary Materials. Sacramento, California: CSWMB 
EI Cerrito Parks and Recreation Department

1978 Summary of Monthly Reports on El Cerrito's MultiMaterials Pick-Up Program. El Cerrito, California: City Parks and Recreation Dept (unpublished).

Franklin, W. E.

1973 Resource Recovery: The State of Technology. Kansas City, Missouri: Midwest Research Institute (PB-214 149)

Garretson, Elmendorf, Zinov and Reibin

1978 a Solid Waste Management Center Phase One - June, 1978. Berkeley, California: City of Berkeley Public Works Department.

Garretson, Elmendorf, Zinov and Reibin

1978 b Solid Waste Management Center Phase Two - September, 1978. Berkeley, California: City of Berkeley Public Works Department.

General Electric Company

1975 Solid Waste Management Technology Assessment New York, N.Y.: Van Nostrand Reinhold Company

GIass Containers Corporation

1978 Personal Correspondence with Pickett Scott, vice president, Glass Container Corporation. Fullerton, California: G.C.C.

Gordian Associates, Inc.

1977 Overcoming Institutional Barriers to Solid Waste Utilization as an Energy Source. Washington, D. C.: Department of Energy.

Hart, Charles

1977 Recycling in Davis: Hand-in-Hand with Garbage Collection Davis, California: Davis Waste Removal Company (unpublished)

Holloway, Robert

1978 Phone conversation. Office of Solid Waste Management, Environmental Protection Agency, Washington, D.C. (October, 1978).

Horner \& Shifrin, Inc.

1973 Solid Waste as Fuel for Power Plants Washington, D.C.: EPA

Howard, Stephen

1976 Market Locations for Recovered Materials Washington, D.C.: U.S. Environmental Protection Agency 
Lawrence Berkeley Laboratory

1977 Analysis of the California Energy Industry. Berkeley, Calfornia: Energy and Fnvironment Division, Energy Analysis Program (LBL 5928, TID 4500 R65).

Levy, Steven and H. Gregor Rigo

1976 Resource Recovery Plant Implementation: Guides for Municipal Officials, Technologies. Washington, D.C.: Environmental Protection Agency.

Lidstrom, R.E.

1974 Energy Effectiveness Diagram for Milwaukee Resource Recovery Facility Greenwich, Connecticut: Americology Division, American Can Company (unpublished)

Lipshutz, Tania

1978 Garbage-To-Energy, The False Panacea Santa Rosa, California: Santa Rosa Recycling Center

Livermore Disposal Company

1978 Phone conversation with William Brandy, director of Livermore California's recycling program.

Martin, Fred

1977 Energy Comparison of Four Alternative Resource Recovery Systems Palo Alto, California (unpublished)

Mathematical Sciences, Northwest

1974 Feasibility Study Conversion of Solid Waste to Methanol or Ammonia Seattle, Washington: City of Seattle, Department of Lighting •

National Association of Recycling Industries

1978 Energy: Recycled Metals Imput on Energy Savings Startling, NARI Eco-Technie News, \#10, March 13

Olsen, Christine

1978 Recycling: The State of The Art Santa Barbara, California: Community Environmental Council

Portland Recycling Team

1975 Resource Conservation Through Citizen Involvement In Waste Management, A Report to the Metropolitan Service District Portland, Oregon: Portland Recycling Team

Preston, G. T.

1976 "Resource Recovery and Flash Pyrolysis of Municipal Refuse," in Clean Fuels From Biomass, Sewage, Urban Refuse, Agricultural Wastes, Symposium Papers. Chicago, Illinois: Institute of Gas Technology. 
Quimby, Thomas

1975 Recycling, The Alternative to Disposal Ealtimore, Maryland: John Hopkins University Press

Recycle 3

1978 Monthly Reports to the State Solid Waste Management Board on Santa Rosa's Multi-material Collection Program Santa Rosa, California: Recycle 3 (unpublished)

Resource Planning Associates

1976 Source Separation. The Community Awareness Program in Somerville and Marblehead, Massachusetts Washington, D.C.: U.S. Environmental Protection Agency

Resource Planning Associates, Inc.

1978 a Solid Waste Recovery Programs in Somerville and Marblehead, Massachusetts Waste Composition Analyses: Interim Report, Fall 1977 Washington, D.C.: Environmental Protection Agency.

Resource Planning Associates, Inc.

1978b Solid Waste Recovery Programs in Somerville and Marblehead, Massachusetts, Monthly Reports: January 1977 through December 1977 Washington, D.C.: Environmental Protection Agency (draft)

Resource Planning Associates, Inc.

1978 c Solid Waste Recovery Programs in Somerville and Marblehead, Massachusetts: Citizen Attitude Telephone Survey Washington, D.C.: Environmental Protection Agency (draft)

Resource Planning Associates, Inc.

1978d Solid Waste Recovery Programs in Somerville and Marblehead, Massachusetts Waste Composition Analysis: Interim Report, Winter 1978 Washington, D.C.: Environmental Protection Agency (draft)

Resource Technology Corporation

1978 Guidelines for Resource Recovery from Municipal Wastes San Jose, California: Resource Technology Corporation

Ritschard, Ronald, Haven, K. 1978 Characterization of Solid Waste Conversion and Cogeneration Systems. Berkeley, California: Energy and Environment Division, Lawrence Berkeley Iab (preliminary draft report). 
SCS Engineers

1976 Evaluation of a Compartmentalized Refuse Collection Vehicle for Separate Newspaper Collection. Long Beach, California: SCS Engineers.

Wentworth $M$.

1977 Resource Recovery: Truth and Consequences. Washington, D.C.: Environmental Action Foundation.

Stefanelli, Leonard

1978 a Presentation to the Honorable Members of the Resource Conservation Committee San Francisco, California: Envirocal/Sunset Scavenger Company (unpublished)

Stefanelli, Leonard

$1978 \mathrm{~b}$ Presentation to the Honorable Members of the Assembly Committee on Resources, Land Use and Energy. San Francisco, California: Envirocal/Sunset Scavenger Co.

U.S. Environmental Protection Agency

1977 a Fourth Report to Congress, Resource Recovery and Waste Reduction Washington, D.C.: E.P.A.

U.S. Environmental Protection Agency

$1977 \mathrm{~b}$ Significance of Size Reduction in Solid Waste Management Cincinnati, Ohio: Municipal Environmental Research Laboratory, office of Research \& Development, U.S. EPA

U.S. Steel

1978 Equipment to Recover Steel from Municipal Solid Waste Pittsburg, Pennsylvania: U.S. Steel 
Appendix

DESCRIPTION OF THE RESOURCE RECOVERY PROCESS

\section{INTRODUCTION}

The recovery of energy from MSW through source separation programs and resource recovery facilities occurs at the back end of a long process -- after virgin materials are transformed into consumable products, distributed, used and ultimately disposed as solid waste. The large diagram which accompanies this text presents an overview of this process and emphasizes other points in the resource stream where energy recovery from materials reclamation can occur. On the following page, a smaller summary diagram provides an outline of the more detailed larger diagram.

Structurally, the diagrams consist of the following components: 1 . The main activities and associated actors and resources; 2. Existing government policies related to these activities; 3 . The motivational concerns of the main actors.

A. THE MAIN ACTIVITIES, RESOURCES AHD ACTORS

These comprise the underlying skeleton of the whole schematic. The six main activities are depicted from left to right across the lower portions of the charts. They include Mining and Harvesting, Manufacturing, Converting, Distributing, Consuming and Disposing. Resources, directly above the main activity in the more detailed diagram, are processed at each of these six stages and change their identities as they move from left to right. For example iron ore, which is at the first mining activity, becomes transformed into steel sheet, then steel cans, food containers and finally a component of consumer garbage.

The resource flow is signified by solid lines which connect with the associated actors at each stage of the process. From different points along these resource paths, scrap materials can be removed and recycled into the main resource flow. In this way, we see a returnable bottle entering a recycling loop through the food store and then re-entering the main path through the beverage maker. The recycling paths are represented by non-solid lines that connect the recycling actors in the upper half of the diagrams with the main activities below.

\section{B. EXISTING POLICIES}

Present government policies influence both the resource and recycling activities at each stage. The former sets of policies are found in the lower portion of the diagrams and are connected directly to the main activities; the latter are found in the top portion of the diagrams and are 
FIGURE 1

THE RESOURCE USE AND RECOVERY PROCESSES

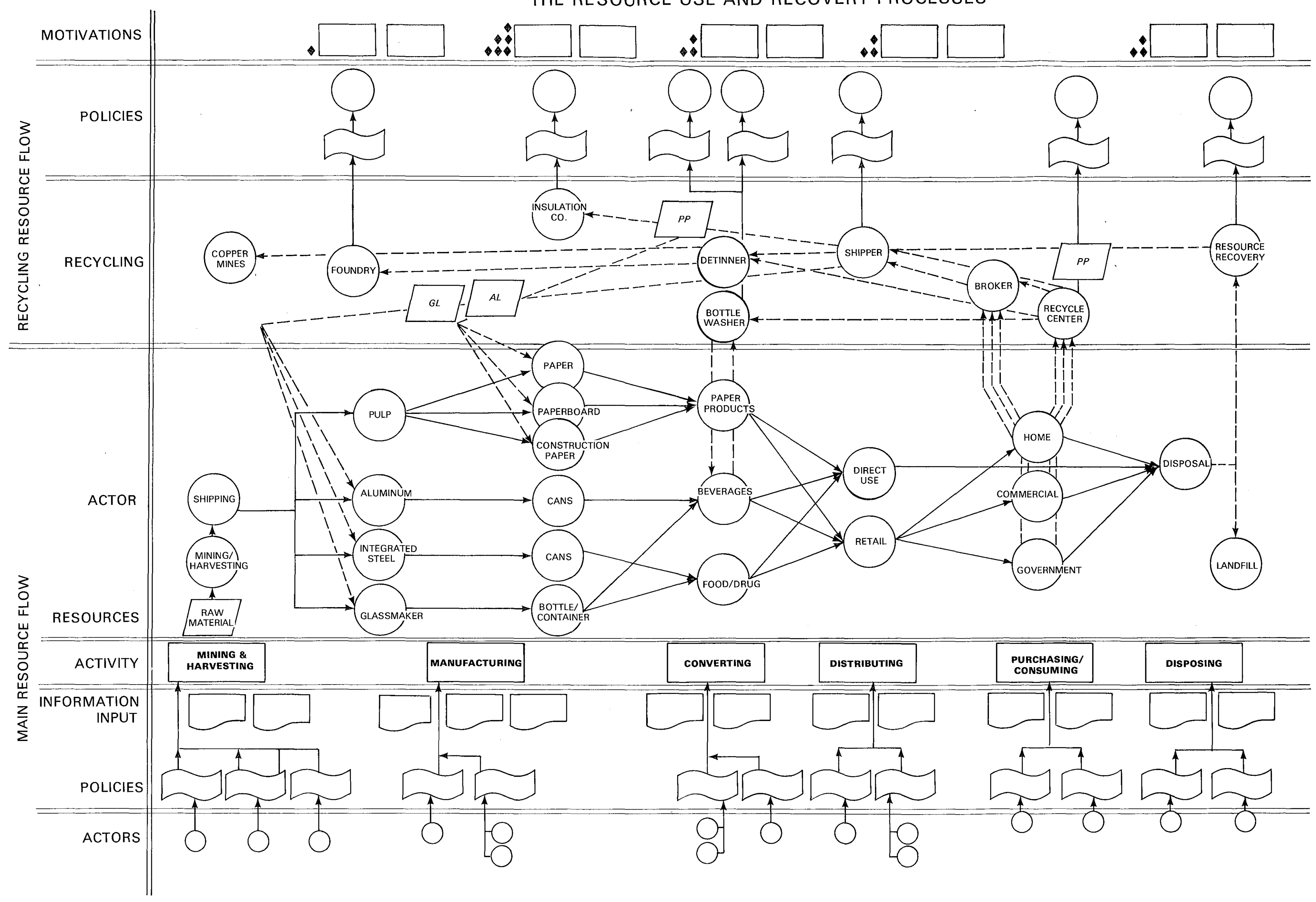


connected directly to the recycling actors which they affect.

C. MOTIVATIONAL CONSIDERATIONS

These are social and economic forces that motivate the main actors along the main resource and recycling paths. For the main resource use actors, these are found directly below the central activity; for the recycling actors, they are shown at the top of the diagrams alongside single or multiple diamonds. The diamonds refer to key decision points where the actors have the choice between recycling material or discarding it, and between using recycled material or virgin material.

II. THF MAIN CHART

A. MINING AND HARVESTING

While recycling - the substitution of used materials for virgin - must by definition occur downstream from the mining and harvesting process, this stage is important to consider for two reasons. First, it serves as a baseline for the evaluation of material and energy recovery levels for recycled materials.

secondly, as the chart illustrates, the industries involved at this stage are assisted in numerous direct and indirect ways by the federal and state governments. This assistance, which is shown as policy inputs in the lower portion of the chart takes the form of tax breaks, government sponsored research and development, favorable leasing arrangements and freight rates. Inasmuch as similar assistance is not provided to the recycling industries, these government policies effectively act to give virgin materials a competitive edge over recycled materials.

\section{B. MANUFACTURING}

Manufacturing is perhaps the most critical stage since it is the maufacturing industries which must ultimately decide whether recovered materials will be used. All other downstream actors are effective in encouraging recycling only to the extent that they can influence this key group of primary materials users to accept scrap.

One of the most critical considerations at this stage is the degree of dependence of the manufacturing firms upon virgin supplies. In particular, the more integrated the manufacturing company, the more likely they are to depend upon their own sources of supply which are grenerally more stable in price and often cheaper than recycled products. For some industries integration has not represented a serious conflict of interest. Notable in this group are the 
integrated aluminum companies, among them Reynolds and Kaiser, which operate succesful reclamation drives as a means of supplementing overseas virgin supply with less expensive sources. Likewise, the glass container industry regards scrap as an inexpensive substitute. Conflicts exist primarily. with the pulp and paper industry which owns or leases large tracts of forest lands, and the steel industry which relies upon virgin ore for its basic oxygen process. Another critical concern at this stage is the capacity of the industry to accept scrap. While glass and aluminum companies currently will purchase all of the scrap available, the large steel and paper companies generally only purchase scrap to make up deficits of virgin purchases. Since both of these materials are linked to key sectors of the economy - buildings in the case of steel and packaging in the case of paper - any downturn in the economy will usually jeopordize purchase of scrap paper and steel cans. Other obstacles to recycling at this stage are outlined alongside the the decision points at the top of the diagram.

\section{CONVERTING}

At this stage, the manufactured products are given their final form - food and beverage containers, newspapers and other forms of paper. Large scale waste such as broken glass and unusable steel cans from food packers and canneries are recycled at this point. The converting industry can also play a role in recycling by requesting certain specifications from the manufacturers - recyclable paper, or returnable bottles, for example. The decision are generally based on cost advantages of the product including its marketability and ease of use.

At the recycling level, only one actor can be classified as a converter. This is the de-tinner who processes the scrap tin cans, removing the tin and producing a clean product for re-sale either to the foundaries or to the copper mines.

While de-tinning is not necessary for sale of the scrap cans, it is necessary for use by most foundaries which insist on a high quality product. Because it is basically a chemical process which produces highly caustic effluents, de-tinning is subject to a number of air and water quality regulations which place restrictions on where these plants can operate.

\section{DISTRIBUTING}

At this stage the consumer products - wine, sodas, beer, newspapers, containerized foodstuffs - are offered to the public through three general outlets: food and drink operations, retail stores and direct suppliers. Because they are in closest contact with the consumer, these operatins are theoretically most responsive to public demand for recycled products. But, more practical considerations may 
prevail. For example, limited storage capacity at a supermarket may cause its manager to minimize the number of returnable containers placed on the shelves.

The equivalent of the distributor at the recycling level is the broker/dealer, an agent who may or may not be directly associated with a manufacturer. The broker/dealer. is the intermediary who purchases scrap on contract or on demand. Some broker/dealers are simply outlets of parent manufacturers, such as Reynolds Recycling which is a wholly owned subsidiary of Reynolds Aluminum.

Others are free agents such as the majority of paper brokers who warehouse the newspaper, usually have a baler and perhaps trucks and storage bins. Brokers are bound to the market price set by manufacturers and are highly constrained by freight prices regulated by the state PUC and the federal ICC.

\section{E. PURCHASING}

At this stage are three general groups that buy the consumer goods: the home user, who chiefly purchases newspapers and goods in cans and bottles; the commercial users who are consumers of paper goods; and the government whose various agencies also primarily consume paper products.

It is here that the majority of recycling - aside from scrap recycled in-house - occurs. Super markets, for example, frequently bale their own cardboard waste and market it. Several state government agencies collect and sell mixed wastepaper and consumers in numerous locales have the option of recycling their discards through recycling centers or curbside collection programs.

These operations can take three forms:those run by non-profit groups, those run by private, profit-making groups including franchised garbage collectors, and those run directly by local governments. Increasingly, these recycling operations are receiving support in the form of government research and development and subsidization. In a few California communities, recyclable materials are collected directly from curbside.

\section{F. DISPOSAL}

The bulk of recyclables are included in municipal solid waste which for the most part is collected in packer trucks and buried in landfill sites. In Californa, $70 \%$ of these collectors are private, although local governments operate the garbage service in the major metropolitan regions of Los Angeles and San Diego.

The major alternative to landfill is centralized resource recovery facilities which produce fuel from MSW and, in many instances, also recover ferrous metals. Some facilities also reclaim aluminum and glass. While no fullscale resource recovery plant has yet been constructed in California, it is included in the diagram because six 
projects are presently being planed to meet the need created as inexpensive and nearby landfill sites are approachir. capacity. 
This report was done with support from the Department of Energy. Any conclusions or opinions expressed in this report represent solely those of the author(s) and not necessarily those of The Regents of the University of California, the Lawrence Berkeley Laboratory or the Department of Energy. 
TECHNICAL INFORMATFON DI ISION

LAWRENCE BERKELEY LABORATORY

UNIVERSITY OF CALIFORNIA

BERKELEY, CALIFORNIA 94720 